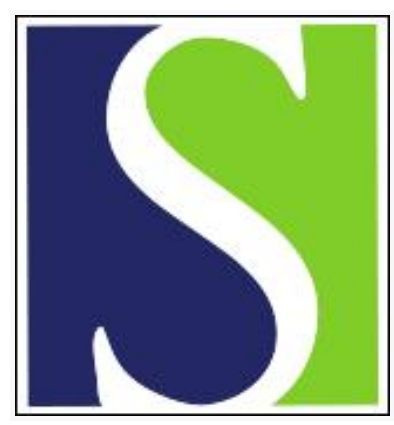

Scand J Work Environ Health 1998;24(3):228-235

https://doi.org/10.5271/sjweh.303

Issue date: Jun 1998

Determinants of airborne rat and mouse urinary allergen exposure

by Hollander A, Heederik D, Doekes G, Kromhout $H$

Key terms: aeroallergens; ambient air; job title; laboratory animal; task

This article in PubMed: www.ncbi.nlm.nih.gov/pubmed/9710376

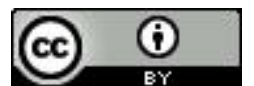




\title{
Determinants of airborne rat and mouse urinary allergen exposure
}

\author{
by Albert Hollander, PhD, ${ }^{1}$ Dick Heederik, PhD, ${ }^{1}$ Gert Doekes, PhD, ${ }^{1}$ Hans Kromhout, PhD'
}

\author{
Hollander A, Heederik D, Doekes G, Kromhout $H$. Determinants of airborne rat and mouse urinary \\ allergen exposure. Scand J Work Environ Health 1998;24(3):228-235.
}

\begin{abstract}
Objectives The purpose of this study was to determine the factors affecting exposure to rat and mouse urinary allergens.

Methods Ambient and personal air sampling was performed on a large scale in 7 laboratory animal facilities.

Results Allergens were mainly present as large particles $(>5.8 \mu \mathrm{m})$. The higher the number of animals in a room, the higher the allergen concentrations. Allergen levels were twice as high on Mondays as on other days due to the tasks performed on Mondays. Filter tops on animal cages were associated with 6-17 times lower ambient allergen levels. An inverse day-night rhythm for rats produced $\geq 10$ times higher rat urinary allergen levels. Personal exposure to rat and mouse urinary allergens differed between job titles but especially between facilities, probably because of differences in task performance and technology. Task-specific sampling revealed that the highest personal exposure levels occurred when contaminated bedding and high numbers of conscious animals were handled. The proportion of time spent on these tasks determined the degree of allergen exposure to a large extent.

Conclusions This study showed that the number of animals present in the room, use of filter top cages, and an inverse day-night thythm were important determinants of rat and mouse urinary allergens in ambient air. Personal exposure to rat and mouse urinary allergens was predominantly determined by the task and site and, to a limited extent, by ambient exposure levels. The presented determinants can be used to develop exposure reduction strategies and also to aid epidemiologic studies of laboratory animal allergy.
\end{abstract}

Key terms aeroallergens, ambient air, job title, laboratory animals, task.

Laboratory animal workers are at high risk of developing occupational allergy $(1-8)$. Several studies $(5,6,9)$ have shown that the risk of developing laboratory animal allergy is related to the allergen exposure level. Exposure control can potentially decrease the risk of developing the disease. Effective exposure control, however, requires detailed knowledge of the most important determinants of exposure $(10,11)$. When available, this kind of knowledge can be used to estimate exposure levels in epidemiologic studies as well (12-14).

Rat and mouse urinary proteins are highly allergenic (15-19) and are the most important allergens in airborne dust in laboratory animal facilities $(16,19)$. In previous studies associations have been found between ambient air levels of urinary allergens and the number of animals in the room $(20-22)$, the bedding material used $(20,23)$, the relative humidity in rooms (24), the use of filter top cages (20), and the rate of ventilation (25). Little is known, however, about the determinants of personal allergen exposure levels of laboratory animal workers.

A large epidemiologic study among approximately 600 laboratory animal workers started in $1992(8,9)$. As part of this epidemiologic study on laboratory animal allery, ambient air sampling in animal rooms, and shift- and task-based personal air sampling was performed. This paper describes an analysis of potential determinants of rat (RUA) and mouse (MUA) urinary aeroallergen exposure. Linear regression models were used to determine the factors affecting RUA and MUA concentrations. In contrast to the findings of other studies $(20,22,26)$, air samples were taken at more than 1 laboratory animal facility. Furthermore, this study had no experimental

1 Department of Environmental Sciences, Environmental and Occupational Health Group, Agricultural University Wageningen, The Netherlands.

Reprint requests to: Dr D Heederik, Department of Environmental Sciences, Environmental and Occupational Health Group, Agricultural University Wageningen, PO Box 238, 6700 AE Wageningen, The Netherlands. [e-mail: dick.heederik@staff.eoh.wau.nl] 
design like most of the earlier studies $(20,23-25)$, but instead examined determinants of exposure to RUA and MUA under normal work conditions.

\section{Materials and methods}

\section{Sites}

Seven laboratory animal facilities, some affiliated with universities (sites A, B, C and D), some nonuniversity research institutes (sites $\mathrm{E}$ and $\mathrm{F}$ ) and a pharmaceutical company (site G), took part in this study. Twenty-one different exposure zones comprising 40 animal rooms were used. A zone was defined on the basis of the work environment (ie, similarity in ventilation system, construction of building or equipment) (27) (table 1).

Five broad job titles could be distinguished. Animal caretakers are involved in "general care of animals" and the cleaning of cages and rooms. Animal technicians carry out experimental procedures on animals on a full-time basis. Scientists and scientific assistants perform experiments on animals and their tissues or body fluids on a part-time basis. Scientific assistants usually perform the routine experiments. Supervisors have no direct contact with animals or their tissues or body fluids but are present in the animal rooms on a regular basis.

\section{Air sampling}

To determine the particle size distribution of the allergencarrying dust, measurements were performed with an Andersen cascade impactor (Andersen, Atlanta, GA, USA). The sampler consisted of 8 stages and a backup. The flow rate was $28.3 \mathrm{l} / \mathrm{min}$. The sampler was placed close to the animals. Altogether 10 samples were collected during full-shift periods of $6-8$ hours, using glass fiber filters (Whatman GF/A).

Total dust ambient-air sampling was carried out at fixed points close to the animals at an average height of $1.5 \mathrm{~m}$.
Total dust concentrations were determined using a modified Schleicher \& Schüll PL050/1 sampling head with a face velocity of $1.25 \mathrm{~m} / \mathrm{s}$ in the inlet opening and a flow rate of $23.5 \mathrm{l} / \mathrm{min}$. Altogether 152 dust samples were collected during full-shift periods of $6-8$ hours, using polytetrafluoroethylene (Teflon) filters (Millipore; pore size $1.0 \mu \mathrm{m}$, diameter $4.5 \mathrm{~cm}$ ). At the time of the sampling, the number of animals in the room was counted, the temperature and relative humidity were measured, and the type of cage and bedding material was recorded. Furthermore, the ventilation rate (air changes per hour) was determined by measuring the inlet or outlet air velocity (heat wire anemometer, Gill 1012 R2). Personal inhalable dust was sampled using IOM (Institute of Occupational Medicine) sampling heads (28) with a flow rate of $21 / \mathrm{min}$. Each sampling head contained a polytetrafluoroethylene (Teflon) filter (Millipore; pore size $1.0 \mu \mathrm{m}$, diameter $2.5 \mathrm{~cm}$ ). Altogether 287 samples were collected during shifts of $4-8$ hours from a random sample of the workers. During the sampling the workers had to record tasks performed on a checklist. Each worker was sampled for 1 week on days worked in the laboratory animal facility. Task-specific personal samples were collected during the following tasks: (i) cleaning rooms and sweeping work zones [mean sampling time 58 (range 10-128) minutes, $\mathrm{N}=15$ rats and 17 mice]; (ii) changing animals from dirty to clean cages and cleaning racks [mean sampling time 73 (range $10-270)$ minutes]; (iii) removing wood chips from dirty cages [mean sampling time 56 (range 7-218) minutes]; (iv) bottle and cage washing in cage washing area [mean sampling time 64 (range 16-112) minutes]; (v) changing animal feed and water bottles [mean sampling time 57 (range 5-186) minutes]; (vi) handling animals in animal room, for example, tumor control, weighing, taking temperature [mean sampling time 85 (range 10-341) minutes]; (vii) immunization, injection, blood sampling [mean sampling time 92 (range 15-325) minutes]; (viii) experimental work on anesthetized animals [mean sampling time 163 (range 25-317) minutes]; and (ix) experimental work on conscious animals, handling and observing [mean sampling time 161 (range 85-267) minutes].

Table 1. Characteristics of the animal rooms of the participating sites.

\begin{tabular}{|c|c|c|c|c|c|c|c|}
\hline Site & $\begin{array}{c}\text { Zones } \\
(\mathrm{N})\end{array}$ & $\begin{array}{l}\text { Rooms } \\
\text { sampled } \\
\text { (N) }\end{array}$ & $\begin{array}{l}\text { Range of rats } \\
\text { per room } \\
\text { (N) }\end{array}$ & $\begin{array}{l}\text { Range of mice } \\
\text { per room } \\
(\mathrm{N})\end{array}$ & $\begin{array}{l}\text { Range of } \\
\text { temperature } \\
\left({ }^{\circ} \mathrm{C}\right)\end{array}$ & $\begin{array}{c}\text { Range of } \\
\text { relative humidity } \\
(\%)\end{array}$ & $\begin{array}{c}\text { Range of } \\
\text { ventilation rate } \\
\text { (air changes per hour) }\end{array}$ \\
\hline A, university & 1 & 2 & $95-200$ & $\ldots$ & $21-21$ & $56-56$ & $34-36$ \\
\hline$B$, university & 7 & 12 & $45-177$ & $250-1000$ & $19-25$ & $37-75$ & $10-36$ \\
\hline$C$, university & 5 & 7 & $22-150$ & $435-900$ & $21-24$ & $45-70$ & $18^{a}$ \\
\hline $\mathrm{D}$, university & 2 & 6 & $100-196$ & $190-350$ & $21-24$ & . & $10-22$ \\
\hline E, research institute & 3 & 6 & $200-416$ & $48-475$ & $20-23$ & $42-70$ & $27-32$ \\
\hline$F$, research institute & 2 & 4 & $45-73$ & $115-360$ & $21-25$ & $45-73$ & $27-34$ \\
\hline G, pharmaceutical company & 1 & 3 & $25-122$ & $25-108$ & $21-22$ & . & $16-22$ \\
\hline
\end{tabular}

a The inlet and outlet of the ventilation system were not accessible. The ventilation rate was obtained from the technical services department of the facility. 


\section{Elution and analysis of urinary aeroallergen to rat and mouse}

RUA and MUA were recovered from the filters by extraction at room temperature with $15 \mathrm{ml}$ (Andersen samples), $4.5 \mathrm{ml}$ (total dust samples), or $2 \mathrm{ml}$ (inhalable dust samples) phosphate buffered saline (PBS, $\mathrm{pH} 7.4$ ). The filters were successively vortexed for 2 minutes, sonicated for 2 minutes, vortexed for 5 minutes, and sonicated for $2 \mathrm{~min}$ utes. The extract was centrifuged at $5000 \mathrm{~g}$ for $15 \mathrm{~min}$ utes, and the supernatant was collected and stored at $-20^{\circ} \mathrm{C}$. The extracts of the Andersen samples (glass fiber filters) were centrifuged twice. RUA and MUA were assayed by sandwich enzyme immunoassays that have been described in detail elsewhere (29). Urine from Wistar rats and $\mathrm{Balb} / \mathrm{c}$ mice was used as standard preparations in the immunoassays. The concentrations in the test samples were expressed in nanograms of urinary protein equivalent (ng eq) per milliliter in which $1 \mathrm{ng}$ eq was defined as the amount giving the same assay result as $1 \mathrm{ng}$ of protein of the standard.

The detection limit was estimated by analyzing extracts of 126 blank filters. These filters underwent the same procedures as the loaded filters except for actual air sampling. The average allergen concentrations estimated in these extracts was 0.026 (SD 0.028) $\mathrm{ng} \mathrm{eq} / \mathrm{ml}$ for the RUA assay and 0.018 (SD 0.023) ng eq $/ \mathrm{ml}$ for the MUA assay. Only extracts of air samples with a concentration higher than the mean concentration of these blanks +2 SD were considered positive, which implied a detection limit of $0.075 \mathrm{ng}$ eq/ $/ \mathrm{ml}$ for the RUA and the MUA assay. Due to differences in the sampling time and flow rate, the detection limits were $0.030 \mathrm{ng} \mathrm{eq} / \mathrm{m}^{3}$ for the total dust samples from the ambient air, $0.23 \mathrm{ng} \mathrm{eq} / \mathrm{m}^{3}$ for the personal full-shift samples, and $0.94 \mathrm{ng} \mathrm{eq} / \mathrm{m}^{3}$ for the personal task samples. Two-thirds of these detection limits were assigned to samples in which RUA or MUA were below the limit of detection.

\section{Statistical analyses}

Potential determinants of the exposure were included in classical linear regression models (SAS, version 6.09, procedure GLM) to help define factors affecting the RUA and MUA concentrations in ambient and personal air samples. Determinants which did not contribute to the model $(P>0.1)$ were excluded from the model. In the analyses, the logarithm of the RUA and MUA concentrations was used to stabilize the variance. Continuous (eg, the number of animals) and dummy [eg, the use of filter top cages (yes;no)] variables were used as independent variables in the empirical models. The logarithm of the number of animals was used to obtain a linear relationship with the RUA and MUA concentrations. Residuals, partial regression plots and influence statistics (Cook's D) were inspected to evaluate possible violation of the assumptions. The models presented had normally distributed residuals, and there was no evidence of any leverage that affected the estimated contribution of the various determinants of exposure.

\section{Results}

Ambient-air dust sampling was performed in 16 of the 21 zones in a total of 40 rooms. The remaining 5 zones were not accessible for our ambient-air sampling equipment because of possible contamination of the animals. Some characteristics of the animal rooms are given in table 1 . The average number of animals was 128 in the rat rooms and 404 in the mouse rooms. At site C, the filter top cages were used in 1 mouse and 1 rat room. In 1 rat room at site $\mathrm{G}$, infrared lights were used to achieve an inverse daynight rhythm. The ventilation rate in all the animal rooms was in between $10-25$ air changes per hour, except for the animal rooms at site $A, B_{\text {zone } 6}, \mathrm{E}_{\text {zone 2 }}$, and $F$, where the ventilation rate was more than 25 air changes per hour. Furthermore, the average temperature of the air in the room was 22 (range $19-25)^{\circ} \mathrm{C}$, and the average relative humidity was 58 (range $37-75$ )\%. Of the 152 total dust samples from the ambient air, 83 were collected in rat rooms, 61 in mouse rooms, and 8 in rooms in which both rats and mice were present. The median RUA concentration in the rat rooms was $0.90 \mathrm{ng} \mathrm{eq} / \mathrm{m}^{3}$ versus $0.020 \mathrm{ng}$ $\mathrm{eq} / \mathrm{m}^{3}$ in the mouse rooms. The median MUA concentration in the mouse rooms was $7.2 \mathrm{ng} \mathrm{eq} / \mathrm{m}^{3}$ versus 0.020 $\mathrm{ng} \mathrm{eq} / \mathrm{m}^{3}$ in the rat room. Fifty-one percent of the samples in the rat rooms had no detectable MUA level, and in the mouse rooms the RUA could not be detected in $85 \%$ of the air samples.

Regression analysis revealed that the logarithm of the number of animals in the room explained most of the variability in the logarithm of the RUA and MUA concentrations. Other important determinants were the use of filter top cages, the use of infrared lights, and the day of the week the sample was taken (tables 2 and 3 ). The presented models explained $66 \%$ and $80 \%$ of the variability of RUA and MUA levels in the ambient air, respectively. No additional variability in the RUA and MUA levels could be explained by the other variables, such as volume, ventilation rate, temperature, and humidity of the room. Doubling the number of rats or mice would increase the RUA or MUA levels 1.6 and 1.8 times, respectively. The estimated RUA concentration was approximately 8 times higher in a rat room housing the maximum number of rats observed $(\mathrm{N}=416)$ compared with a similar rat room housing the minimum number of rats observed (22). For mouse rooms this difference was even larger, approximately 14 times. In rooms with filter tops on the cages the RUA and MUA levels were approximately 6 and 17 times lower 
Table 2. Analysis of variance model of ambient rat urinary aeroallergen (RUA) concentrations on various animal room characteristics [outcome variable: $\log 10$ (RUA concentration)]. (residual $\mathrm{SD}=0.58)$

\begin{tabular}{|c|c|c|c|c|c|c|c|}
\hline & df & SS & MS & $\mathrm{F}$ & $\mathrm{P}$ & $\mathrm{R}^{2}$ & $\beta^{\mathrm{a}}(\mathrm{SE})$ \\
\hline \multicolumn{8}{|l|}{ Source } \\
\hline $\begin{array}{l}\text { Model } \\
\text { Error }\end{array}$ & $\begin{array}{r}4 \\
146\end{array}$ & $\begin{array}{l}97.4 \\
50.4\end{array}$ & $\begin{array}{l}24.4 \\
0.35\end{array}$ & 70.6 & 0.0001 & 0.659 & \\
\hline \multicolumn{8}{|l|}{ Characteristic } \\
\hline $\begin{array}{l}\text { Log (number } \\
\text { of rats in room) } \\
\text { Monday versus }\end{array}$ & 1 & $79.0^{\mathrm{b}}$ & & 229 & 0.0001 & . & $0.72(0.05)$ \\
\hline $\begin{array}{l}\text { Tuesday-Friday } \\
\text { Filter top on cages }\end{array}$ & $\begin{array}{r}1 \\
\text { es } 1\end{array}$ & $\begin{array}{l}1.3^{\mathrm{b}} \\
4.5^{\mathrm{b}}\end{array}$ & & $\begin{array}{l}3.8 \\
13.1\end{array}$ & $\begin{array}{l}0.0519 \\
0.0004\end{array}$ & . & $\begin{array}{c}0.26(0.13) \\
-0.77(0.21)\end{array}$ \\
\hline in roome & 1 & $4.2^{\mathrm{b}}$ & & 12.2 & 0.0010 & . & $1.05(0.30)$ \\
\hline
\end{tabular}

a For the estimation of the geometric mean for a given set of conditions, the background level $\left(0.023 \mathrm{ng} \mathrm{eq} / \mathrm{m}^{3}\right)$ should be multiplied by $10^{\text {( } \beta \times \text { factors }}$ ( $(\mathrm{eg}$ 80 rats in open cages with normal lights will give an estimated RUA concentration on a Monday of $10^{(0.72 \times \log (80)+0.26 \times 1-0.77 \times 0+1.05 \times 0) \times 0.023=}$ $0.98 \mathrm{ng} \mathrm{eq} / \mathrm{m}^{3}$.

${ }^{b}$ Type Ill SS.

c Infrared lights were used to achieve an inverse day-night rhythm.

Table 3. Analysis of variance model of ambient mouse urinary aeroallergen (MUA) concentrations on various animal room characteristics [outcome variable: $\log 10$ (MUA concentration)]. (residual $S D=0.52$

\begin{tabular}{|c|c|c|c|c|c|c|c|}
\hline & df & SS & MS & $\mathrm{F}$ & $P$ & $\mathrm{R}^{2}$ & $\beta^{\mathrm{a}}(\mathrm{SE})$ \\
\hline \multicolumn{8}{|l|}{ Source } \\
\hline $\begin{array}{l}\text { Model } \\
\text { Error }\end{array}$ & $\begin{array}{r}3 \\
146\end{array}$ & $\begin{array}{r}163.9 \\
40.0\end{array}$ & $\begin{array}{l}54.61 \\
0.27\end{array}$ & 199.4 & 0.0001 & 0.804 & . \\
\hline \multicolumn{8}{|l|}{ Characteristics } \\
\hline $\begin{array}{l}\text { Log (number } \\
\text { of mice in room) } \\
\text { Monday versus }\end{array}$ & 1 & $153.6^{b}$ & & 560 & 0.0001 & & $0.82(0.03)$ \\
\hline $\begin{array}{l}\text { Tuesday-Friday } \\
\text { Filter top on cages }\end{array}$ & $\begin{array}{l}1 \\
s \\
1\end{array}$ & $\begin{array}{r}2.6^{\mathrm{b}} \\
11.5^{\mathrm{b}}\end{array}$ & & $\begin{array}{r}9.6 \\
42.0\end{array}$ & $\begin{array}{l}0.0023 \\
0.0001\end{array}$ & & $\begin{array}{r}0.36(0.11) \\
-1.24(0.19)\end{array}$ \\
\hline
\end{tabular}

a For the estimation of the geometric mean for a given set of conditions, the

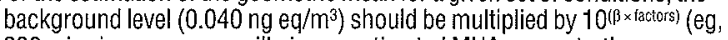
290 mice in open cages will give an estimated MUA concentration on a Monday of $10^{(0.82 \times 10 \mathrm{og}(290)+0.36 \times 1-1.24 \times 0)} \times\left(0.040=9.6 \mathrm{ng} \mathrm{eq} / \mathrm{m}^{3}\right.$. ${ }^{\circ}$ Type Ill SS.

Table 4. Mean and ranges of the distribution of allergen particles, presented as a percentage of the total urinary aeroallergen concentration.

\begin{tabular}{|c|c|c|c|c|}
\hline \multirow{2}{*}{$\begin{array}{l}\text { Aerodynamic } \\
\text { diameter } \\
(\mu \mathrm{m})\end{array}$} & \multicolumn{2}{|c|}{ Rat $(\mathrm{N}=4)$} & \multicolumn{2}{|c|}{ Mouse $(N=6)$} \\
\hline & Mean $(\%)$ & Range & Mean $(\%)$ & Range \\
\hline $\begin{array}{l}>9.0 \\
5.8-9.0 \\
4.7-5.8 \\
3.3-4.7 \\
2.1-3.3 \\
<2.1^{a}\end{array}$ & $\begin{array}{r}78 \\
22 \\
0 \\
0 \\
0 \\
0\end{array}$ & $\begin{array}{c}62-100 \\
0-38 \\
- \\
- \\
- \\
-\end{array}$ & $\begin{array}{r}47 \\
25 \\
8 \\
8 \\
8 \\
4\end{array}$ & $\begin{array}{l}22-64 \\
20-33 \\
1-13 \\
1-16 \\
1-25 \\
0-6\end{array}$ \\
\hline $\begin{array}{l}\text { Total allergen } \\
\text { concentration } \\
\text { (ng eq/m } / \mathrm{m}^{3} \text { ) }\end{array}$ & 0.57 & $0.13-0.90$ & 14.8 & $3.6-37.8$ \\
\hline
\end{tabular}

a Four stages of the Andersen sampler were grouped.
Table 5. Analysis of variance model of the personal shift rat urinary aeroallergen $(R \cup A)$ concentrations [outcome variable: $\log 10$ (RUA concentration)]. (residual $S D=0.72$ )

\begin{tabular}{|c|c|c|c|c|c|c|c|}
\hline & $d f$ & SS & MS & $F$ & $P$ & $\mathrm{R}^{2}$ & $\beta^{a}(S E)$ \\
\hline \multicolumn{8}{|l|}{ Source } \\
\hline $\begin{array}{l}\text { Model } \\
\text { Error }\end{array}$ & $\begin{array}{r}11 \\
239\end{array}$ & $\begin{array}{r}36.2 \\
128.2\end{array}$ & $\begin{array}{r}3.3 \\
0.54\end{array}$ & 6.1 & 0.0001 & 0.22 & . \\
\hline \multicolumn{8}{|l|}{ Characteristic } \\
\hline Job title & 4 & $6.6^{\mathrm{b}}$ & & 3.1 & 0.018 & & \\
\hline $\begin{array}{l}\text { Animal caretaker } \\
\text { Animal techniciar } \\
\text { Scientific assistar } \\
\text { Scientist } \\
\text { Supervisor }\end{array}$ & & & & & & $\begin{array}{l}. \\
. \\
.\end{array}$ & $\begin{array}{c}0.38(0.24) \\
0.02(0.26) \\
-0.33(0.33) \\
0.17(0.24) \\
0\end{array}$ \\
\hline Site & 6 & $23.7^{\mathrm{b}}$ & & 7.4 & 0.0001 & & \\
\hline $\begin{array}{l}A \\
B \\
C \\
D \\
E \\
F \\
G\end{array}$ & & & & & & . & $\begin{array}{c}-0.54(0.94) \\
0.60(0.57) \\
0.21(0.57) \\
1.02(0.57) \\
0.55(0.59) \\
1.46(0.60) \\
0\end{array}$ \\
\hline $\begin{array}{l}\text { Monday versus } \\
\text { Tuesday-Friday }\end{array}$ & 1 & $4.4^{b}$ & & 8.3 & 0.0045 & & $0.37(0.13)$ \\
\hline
\end{tabular}

a For the estimation of the geometric mean for a given set of conditions, the background level $\left(0.15 \mathrm{ng} \mathrm{eq} / \mathrm{m}^{3}\right)$ should be multiplied by $10^{\text {( } \$ \text { f factors) }}$ (eg an animal caretaker at site $B$ will have an estimated RUA concentration on a Monday of $10^{(0.38+0.60+0.37 \times 1)} \times 0.15=3.4 \mathrm{ng} \mathrm{eq} / \mathrm{m}^{3}$. b Type III SS.

Table 6. Analysis of variance model of the personal shift mouse urinary aeroallergen (MUA) concentrations [outcome variable: $\log 10$ (MUA concentration)]. (residual $S D=0.87$ )

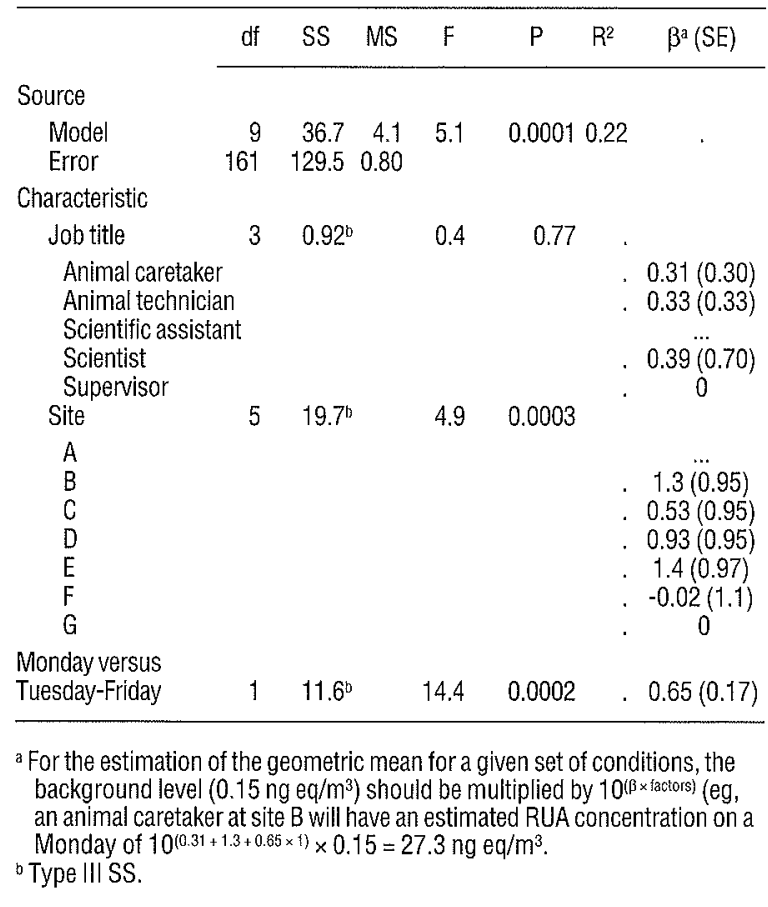

than the levels found in similar rooms without filter tops on the cages. The RUA and MUA levels were approximately twice as high on Mondays than on the other days of the week. Furthermore, in the rat rooms where rats were 
kept with an inverse day-night rhythm, the RUA levels were about 11 times higher than the RUA levels found in normal rat rooms.

Table 4 shows the size distribution of the dust particles carrying allergens. The RUA values were carried on particles larger than $5.8 \mu \mathrm{m}$ in diameter, and $78 \%$ of the total allergen level in a sample was found on particles with a diameter larger than $9 \mu \mathrm{m}$. The majority of the MUA values was also found on particles larger than $5.8 \mu \mathrm{m}$ in diameter $(72 \%)$.

Of the 287 4- to 8-hour personal inhalable dust samples, 116 were collected during work with only rats, 36 during work with only mice, and 135 during work with rats and mice. The personal dust concentrations were low and showed little variation over time and between jobs (range $0.11-0.64 \mathrm{mg} / \mathrm{m}^{3}$ ), whereas the variability of the aeroallergen concentrations was large. The median RUA and MUA concentrations of all the samples were $0.76 \mathrm{ng}$ $\mathrm{eq} / \mathrm{m}^{3}$ and $6.4 \mathrm{ng} \mathrm{eq} / \mathrm{m}^{3}$, respectively. The variability in the RUA and MUA exposure was large with a 175- and 1400-fold difference between the 5th and 95 th percentiles of the distributions, respectively. Of the large variability in both the RUA and MUA concentrations, $22 \%$ was explained by job title, site, and day of the week the sample was taken (tables 5 and 6). The animal technicians and supervisors had similar median RUA exposure levels of 0.77 and $0.65 \mathrm{ng} \mathrm{eq} / \mathrm{m}^{3}$. For the scientists and scientific assistants more than half of the samples were below the detection limit. For MUA the highest exposure levels were found for the animal technicians (median 12.1 $\mathrm{ng} \mathrm{eq} / \mathrm{m}^{3}$ ) and caretakers (median $6.4 \mathrm{ng} \mathrm{eq} / \mathrm{m}^{3}$ ), and the lowest exposure levels were found for the supervisors (median $0.58 \mathrm{ng} \mathrm{eq} / \mathrm{m}^{3}$ ). For the scientists only 2 air samples were collected during work with mice. Site explained most of the variability in the RUA and MUA exposure, giving a 100- and 23-fold difference in the estimated RUA and MUA exposure between the sites with the lowest and highest exposure. The RUA and MUA levels of the personal shift samples were higher on Mondays than on the other days of the week, 2.3 and 4.5 times, respectively.
The 278 task-specific personal inhalable dust samples included 46 4- to 8-hour shift samples that entailed only 1. task. Altogether 155 samples were collected during work with rats, 82 during work with mice, and 41 during work with both rats and mice. The exposure levels by task are given in table 7 . Respectively, $62 \%$ and $18 \%$ of the samples had no detectable RUA or MUA levels. The tasks of changing rats into new cages and cleaning out cages were associated with the highest exposure to RUA. During all other tasks the median RUA levels were below the detection limit. Tasks that involved the handling of contaminated bedding or experiments with large numbers of conscious mice were associated with the highest exposure to MUA. During changing mice into new cages, the handling of mice, feeding, and biotechnological work, intermediate levels of MUA were found. Tasks entailing indirect contact with mice, like cage washing and cleaning animal rooms, were associated with the lowest MUA exposure. Regression analysis revealed that task, site, and the interaction between task and site explained $56 \%$ and $51 \%$ of the variability in the RUA and MUA levels, respectively (RUA: $F=10.5$, $\mathrm{df}=21, \mathrm{P}=0.001$, residual $\mathrm{SD}=0.48$; MUA: $\mathrm{F}=5.6, \mathrm{df}=19, \mathrm{P}=0.001$, residual $\mathrm{SD}=0.67)$. In these analyses the tasks of feeding and handling animals were grouped, as well as the tasks of room or cage washing, biotechnological work, and experiments. This grouping resulted in a total of 4 tasks. Again, cleaning out cages was associated with the highest RUA and MUA exposure, although clear differences in exposure between sites were observed for this task. The interaction between site and task explained a large amount of the variability in RUA and MUA exposure (approximately $20 \%$ in both models).

Table 8 shows the average proportion of time spent on the various tasks during contact with rats or mice, tissues, feces, or urine. Animal caretakers worked the most of all workers with rats or mice. During approximately $80 \%$ of their time spent working with animals they were involved in feeding, cleaning rooms or cages, and moving animals to new cages. Animal technicians, scientists,

Table 7. Geometric mean (GM), geometric standard deviation (GSD), and range of airborne RUA and MUA task-specific personal exposure levels ( $\left.\mathrm{ng} \mathrm{eq} / \mathrm{m}^{3}\right)(\mathrm{N}=196$ for RUA exposure, $\mathrm{N}=123$ for MUA exposure). (ND = number of samples below the detection limit)

\begin{tabular}{|c|c|c|c|c|c|c|c|c|c|c|}
\hline \multirow[t]{2}{*}{ Task } & \multicolumn{5}{|c|}{ Rat } & \multicolumn{5}{|c|}{ Mouse } \\
\hline & $\mathrm{N}$ & ND & $\begin{array}{c}\mathrm{GM} \\
\left(\mathrm{ng} \mathrm{eq} / \mathrm{m}^{3}\right)^{\mathrm{a}}\end{array}$ & GSD & Range & N & ND & $\begin{array}{c}G M \\
\left(n g e q / m^{3}\right)^{a}\end{array}$ & GSD & Range \\
\hline Cleaning out cages & 29 & 12 & 5.6 & 9.8 & $0.63-1600$ & 25 & 1 & 74.8 & 9.2 & $0.63-2700$ \\
\hline Changing into new cages & 35 & 10 & 5.3 & 5.4 & $0.63-127$ & 33 & 3 & 22.8 & 6.5 & $0.63-501$ \\
\hline Feeding & 20 & 11 & 2.4 & 5.3 & $0.63-60$ & 19 & 2 & 19.6 & 7.8 & $0.63-542$ \\
\hline Handling animals & 34 & 22 & 1.2 & 3.7 & $0.63-94$ & 8 & 1 & 16.0 & 5.7 & $0.63-209$ \\
\hline Experiments 2 & 7 & 5 & 1.0 & 2.5 & $0.63-6.3$ & 2 & 0 & 33.5 & 7.5 & $8.0-140$ \\
\hline Experiments 1 & 25 & 20 & 0.85 & 2.2 & $0.63-9.0$ & & & & & \\
\hline Biotechnical work & 23 & 21 & 0.83 & 2.6 & $0.63-34$ & 11 & 2 & 5.4 & 4.2 & $0.63-51$ \\
\hline Cage wash & 8 & 7 & 0.81 & 2.1 & $0.63-4.9$ & 8 & 4 & 2.6 & 6.4 & $0.63-89$ \\
\hline Cleaning rooms & 15 & 13 & 0.80 & 2.2 & $0.63-14$ & 17 & 9 & 2.4 & 5.6 & $0.63-151$ \\
\hline
\end{tabular}

ang eq = ng protein equivalent. 
Table 8. Proportiona of time spent on various tasks during contact with rats or mice or with tissues, feces or urine from rats or mice and hours per week working with laboratory animals.

\begin{tabular}{|c|c|c|c|c|c|c|c|c|c|}
\hline Job title & $\begin{array}{l}\text { Cleaning } \\
\text { rooms }\end{array}$ & $\begin{array}{l}\text { Change to } \\
\text { new cages }\end{array}$ & $\begin{array}{c}\text { Cleaning } \\
\text { cages }\end{array}$ & $\begin{array}{c}\text { Cage } \\
\text { washing }\end{array}$ & Feeding & $\begin{array}{l}\text { Handling } \\
\text { animals }\end{array}$ & $\begin{array}{l}\text { Biotechnical } \\
\text { work }\end{array}$ & Experiments 1 & $\begin{array}{l}\text { Hours per week } \\
\text { working with } \\
\text { laboratory animals }\end{array}$ \\
\hline Animal caretaker & 19 & 2 & 19 & 14 & 24 & 8 & 2 & 2 & 27 \\
\hline Animal technician & 10 & $<1$ & 7 & 5 & 17 & 10 & 33 & 12 & 16 \\
\hline Scientific assistant & 6 & 9 & $<1$ & $<1$ & 3 & 4 & 9 & 47 & 5 \\
\hline Scientist & $<1$ & 2 & $<1$ & $<1$ & 3 & 29 & 19 & 40 & 5 \\
\hline Supervisor & 22 & $<1$ & 6 & 14 & 15 & 17 & 4 & $<1$ & 3 \\
\hline
\end{tabular}

a This proportion does not add up to $100 \%$ for each job title because a small proportion was spent on miscellaneous tasks.

b This figure was derived from the health-exposure questionnaire which was distributed to all the workers of the participating facilities (8).

and scientific assistants worked fewer hours per week with mice or rats, and their work with laboratory animals consisted of more than $50 \%$ of handling animals, biotechnological work, and experiments on anesthetized animals. Normally, supervisors have no direct contact with animals, but, due to leaves of absence of other workers, they had to take over the other workers' tasks occasionally (ie, an average of 3 hours per week).

\section{Discussion}

Large differences in RUA and MUA concentrations were found in the ambient air when various animal rooms were compared. The number of animals in the room explained more than $50 \%$ of the variability in the allergen concentrations. Other important exposure determinants of the ambient exposure levels were the activity of the animals and the use of filter top cages. The use of an inverse day or night rhythm, which makes rats more active during workhours, resulted in considerably higher RUA levels in the rooms. These observations under field conditions are consistent with findings from other, mostly experimental studies, where the aeroallergen concentrations in rooms increased when the animals were disturbed $(23,26,30)$. The use of filter top cages seems to be a useful control measure, also under field conditions, to reduce the allergen level in the ambient air of the rooms. In rat and mouse rooms where filter tops were used, the RUA and MUA concentrations were 6 and 17 times lower, respectively, than in similar rooms without filter top cages. This finding is consistent with the results of an experimental study (20), in which the RUA concentration of the ambient air was reduced by filter tops to levels similar to those found in the same room in the absence of rats.

As observed in some other studies, animal caretakers had the highest personal RUA and MUA exposure because they spent the largest proportion of their worktime on cleaning out cages, which involves handling contaminated bedding material, and handling large numbers of conscious animals $(31-33)$. On Mondays the ambient air levels and the personal RUA and MUA levels were significantly elevated when compared with the levels on the other days of the week, mainly due to cleaning activities.

Cleaning tasks, feeding, and handling animals were related to high allergen exposures. Within task categories, large differences in task-specific exposures between sites were observed. This finding suggests that unaccounted for site-specific determinants might play a role. Differences in cleaning technology (exhaust ventilation near cleaning tables) and feeding technology between sites are the most likely explanations for the large variation that could be attributed to a site effect within task categories. The influence of determinants of exposure on full-shift personal exposure measurements could not be determined directly. Workers often performed a task in more than 1 room with different room characteristics (ventilation, etc) and animal densities. Several tasks (cleaning cages, cage washing, biotechnological work, and experiments) were not performed in the animal rooms. As a result, determinants of personal exposure differ to some extent from the determinants of ambient exposure in animal rooms. Other unmeasured factors may also contribute to the differences in personal exposure levels, such as the level of contamination of the bedding material, personal behavior of the worker, and type and varying levels of local ventilation equipment or other exposure control equipment. These results indicate that lowering ambient allergen exposure levels in animal rooms will have only limited impact on the personal exposure of some categories of workers, especially animal caretakers and animal technicians. It seems important to focus preventive strategies more on the determinants of (full-shift or task-specific) personal exposure.

This assumption is also supported by other observations. The average personal exposure levels of the highest exposed tasks were approximately 10 times higher than the average ambient air levels found in the animal rooms, probably because cleaning tasks, feeding, and animal handling contributed the most to the personal exposure levels. The factor 10 is probably an underestimation of the true difference because only filters were assayed. The dust captured on the cone of the sampling head was not included in the biochemical analysis. The ambient 
exposure levels were overestimated when compared with the levels in inhalable dust samples, because dust was sampled according to the total dust convention (34).

The large influence of site is similar to results found in some other industries $(10,12)$, but it is in contrast to the findings of another study in laboratory animal facilities (35). In the latter study, job title explained a much larger percentage of the variability in RUA levels than differences between sites. A possible explanation is the larger number of sites sampled in this study (35).

Empirical modeling as used has several limitations. A large proportion of the variance in personal RUA and MUA levels remained unexplained in the linear models because of factors not accounted for in this study. In addition, the evaluation was restricted to explanatory variables with sufficient variation. An important difference with other studies $(20,22,26)$ is that our study was performed at different sites, which should account for sufficient variation in the various variables. Despite the large number of sites in our study, we could not find any association between ambient air allergen concentrations and the rate of ventilation and relative humidity in the room, a finding which is in contrast to those of other studies $(24,25,36)$. The reasons for these discrepancies are not clear, but they could be associated with the limited influence of ventilation when compared with the influence of other strong determinants of exposure or the dependence between the ventilation rate and other determinants of exposure.

RUA and MUA were found mainly on particles larger than $5.8 \mu \mathrm{m}$, a finding consistent with findings of other studies $(20,23,30,37,38)$. These particles are probably deposited in the nose and upper airways (39).

In another paper (9) we described a relationship between exposure to RUA and the prevalence rate of rat allergy. At low "time-multiplied exposure" levels (<1-hour weekly nanograms of urinary protein equivalent per cubic meter) $9 \%$ of the "atopic" workers had an allergy to rats. Among the "nonatopic" workers, allergy to rats was not present in the lowest exposure group. Such a low "time-multiplied exposure" level would already be reached by changing rats for about 9 minutes per week or being in an average rat room for slightly more than 1 hour. Consequently, a considerable reduction in exposure is necessary for this group of sensitive workers (ie, "atopic" workers) to be able to work under normal conditions with a low risk of developing occupational allergy.

\section{Acknowledgments}

The authors wish to thank Joost Thissen, Els Frankhuijzen, Paula van Run, and Isabella van Schothorst for their technical assistance and all the laboratory animal workers for their participation in this study.
This study was supported by research grants from The Netherlands Asthma Foundation, the Ministry of Social Affairs and Employment, and the European Union (contract BMH1-CT94-1446).

\section{References}

1. Cockcroft A, Edwards J, McCarthy P, Andersson N. Allergy in laboratory animal workers. Lancet 1981;1:827-30.

2. Beeson MF, Dewdney JM, Edwards RG, Lee D, Orr RG Prevalence and diagnosis of laboratory animal allergy. Clin Allergy 1983;13:433-42.

3. Bland SM, Levine MS, Wilson PD, Fox NL, Rivera JC. Occupational allergy to laboratory animals: an epidemiological study. J Occup Med 1986;28:1151-7.

4. Venables KM, Tee RD, Hawkins ER, Gordon DJ, Wale CJ, Farrer MN, et al. Laboratory animal allergy in a pharmaceutical company. Br J Ind Med 1988;45:660-6.

5. Kibby T, Powell G, Cromer J. Allergy to laboratory animals: a prospective and cross-sectional study. J Occup Med 1989;31:842-6.

6. Cullinan P, Lowson D, Nieuwenhuijsen MJ, Gordon S, Tee $\mathrm{RD}$, Venables KM, et al. Work related symptoms, sensitisation, and estimated exposure in workers not previously exposed to laboratory rats. Occup Environ Med 1994;51:589-92.

7. Renström A, Malmberg P, Larsson K, Sundblad B-M, Larsson PH. Prospective study of laboratory-animal allergy: factors predisposing to sensitization and development of allergic symptoms. Allergy 1994;49:548- 52 .

8. Hollander A, Doekes G, Heederik D. Cat and dog allergy and total $\mathrm{IgE}$ as risk factors of laboratory animal allergy. $\mathrm{J}$ Allergy Clin Immunol 1996;98:545-54.

9. Hollander A, Heederik D, Doekes G. Respiratory allergy to rats: exposure-response relationships in laboratory animal workers. Am J Respir Crit Care Med. In press.

10. Kromhout H, Swuste P, Boleij JSM. Emperical modelling of chemical exposure in the rubber manufactering industry. Ann Occup Hyg 1994;38:3-22.

11. Preller L, Heederik D, Kromhout H, Boleij JSM, Tielen MJM. Determinants of dust and endotoxin exposure of pig farmers: development of a control strategy using empirical modelling. Ann Occup Hyg 1995;39:545-557.

12. Eisen EA, Smith TJ, Wegman DH, Louis TA, Froines J. Estimation of long term dust exposures in the vermont granite sheds. Am Ind Hyg Assoc J 1984;45:89-94.

13. Preller L, Kromhout H, Heederik D, Tielen MJM. Modeling long-term average exposure in occupational exposure-response analysis. Scand J Work Environ Health 1995;21:504-12.

14. Smid T, Heederik D, Mensink G, Houba R, Boleij JSM. Exposure to dust, endotoxin and fungi in the animal feed industry. Am Ind Hyg Assoc J 1992;53:362-8.

15. Newman Taylor A, Longbottom JL, Pepys J. Respiratory allergy to urine proteins of rats and mice. Lancet 1977;2:847--9.

16. Schumacher MJ. Characterization of allergens from urine and pelts of laboratory mice. Mol Immunol 1980;17:1087 95.

17. Walls AF, Longbottom JL. Comparison of rat fur, urine saliva, and other rat allergen extracts by skin testing,RAST, 
and RAST inhibition. $\mathrm{J}$ Allergy Clin Immunol 1985;75:242-51.

18. Lutsky I, Fink JN, Kidd J, Dahlberg MJE, Yuninger JW. Allergenic properties of rat urine and pelt extracts. J Allergy Clin Immunol 1985;75:279—84.

19. Gordon S, Tee RD, Newman Taylor AJ. Analysis of rat urine proteins and allergens by sodium dodecyl sulfatepolyacrylamide gel electrophoresis and immunoblotting. J Allergy Clin Immunol 1993;92:298-305.

20. Gordon S, Tee RD, Lowson D, Wallace J, Newman Taylor AJ. Reduction of airborne allergenic urinary proteins from laboratory rats. Br J Ind Med 1992;49:416-422.

21. Ohman JL, Hagberg K, MacDonald MR, Jones RR, Paigen BJ, Kacergis JB. Distribution of airborne mouse allergen in a major mouse breeding facility. $\mathbf{J}$ Allergy Clin Immunol 1994;94:810-817.

22. Nieuwenhuijsen MJ, Gordon S, Harris J, Tee RD, Venables KM, Newman Taylor AJ. Determinants of airborne allergen exposure in an animal house. Occup Hyg 1995;1:317-324.

23. Platts-Mills TAE, Heyman PW, Longbottom JL, Wilkins SR. Airborne allergens associated with asthma: particle sizes carrying dust mite and rat allergens measured with a cascade impactor. J Allergy Clin Immunol 1986;77:850-857.

24. Jones RB, Kacergis JB, MacDonald MR, McKnight FT, Turner WA, Ohman JL, et al. The effect of relative humidity on mouse allergen levels in an environmentally controlled mouse room. Am Ind Hyg Assoc J 1995;56:398-401.

25. Swanson MC, Campbell AR, O'Hollaren MT, Reed CE Role of ventilation, air filtration, and allergen production rate in determining concentrations of rat allergens in the air of animal quarters. Am Rev Respir Dis 1990;141:1578-81.

26. Kacergis JB, Jones RB, Reeb CK, Turner WA, Ohman JL, Ardman MR, et al. Air quality in an animal facility: particulates, ammonia, and volatile organic compounds. Am Ind Hyg Assoc J 1996;57:634-40.

27. Corn M, Esmen NA. Workplace exposure zones for classification of employees exposures to physical and chemical agents. Am Ind Hyg Assoc J 1979;40:47-57.

28. Mark D, Vincent JH. A new personal sampler for airborne total dust in workplaces. Ann Occup Hyg 1986;30:89-102.
29. Hollander A, van Run P, Spithoven J, Doekes G, Heederik D. Exposure of laboratory animal workers to airborne rat and mouse urinary allergens. Clin Exp Allergy. In press.

30. Price JA, Longbottom JL. ELISA method for measurement of airborne levels of major laboratory animal allergens. Clin Allergy 1988;18:95-107.

31. Nieuwenhuijsen MJ, Gordon S, Tee RD, Venables KM, McDonald JC, Newman Taylor AJ. Exposure to dust and rat urinary aeroallergens in research establishments. Occup Environ Med 1994;51:593-6.

32. Davies GE, Thompson AV, Rackham M. Estimation of airborne rat-derived antigens by ELISA. J Immunoassay 1983:4:113-26.

33. Eggleston PA, Newill CA, Ansari AA, Pustelnik A, Lou S, Evans III R, et al. Task-related variation in airborne concentrations of laboratory animal allergens: studies with RAT n I. J Allergy Clin Immunol 1989;84:347-52.

34. Vincent JH, Mark D, Miller B, Armbuster L, Ogden TL. Aerosol inhalability at higher wind speeds. J Aerosol Sci 1990:21:577-86.

35. Nieuwenhuijsen MJ, Gordon S, Harris JM, Tee RD, Venables KM, Newman Taylor AJ. Variation in rat urinary aeroallergen levels explained by differences in site, task and exposure group. Ann Occup Hyg 1995;39:819-25.

36. Edwards RG, Beeson MF, Dewdney JM. Laboratory animal allergy: the measurement of airborne urinary allergens and the effects of different environmental conditions. Lab Anim $1983 ; 17: 235-9$

37. Corn M, Koegel A, Hall T, Scott A, Newill C, Evans R. Characteristics of airborne particles associated with animal allergy in laboratory workers. Ann Occup Hyg 1988;32 suppl 1:435-46.

38. Sakaguchi M, Inouye S, Miyazawa H, Kamimura H, Kimura M, Yamazaki S. Particle size of airborne mouse crude and defined allergens. Lab Anim Sci 1989;39:234-6.

39. Lippmann M, Yeates DB, Albert RE. Deposition, retention, and clearance of inhaled particles. $\mathrm{Br} \mathrm{J}$ Ind $\mathrm{Med}$ 1980;37:337-62.

Received for publication: 11 March 1997 